\title{
The proteins of iodine metabolism in the pathophysiology of the thyroid gland
}

\author{
Barbara Czarnocka \\ From 4th Congress of the Polish Thyroid Association 2013 \\ Lodz, Poland. 11-13 April 2013
}

Iodide (I-) is a trace element $(0.0001 \%$ lithosphere) that is an important constituent of thyroid hormones. The iodide-containing T3 and T4 are crucial for normal development and the proper functioning of numerous metabolic pathways in probably all adult tissues. The biosynthesis of T3 and T4 involves thyroid specific proteins, found predominantly but not exclusively in the thyroid tissue. The process requires the presence of iodide (I-), a peroxidase (TPO), a supply of $\mathrm{H} 2 \mathrm{O} 2$, and an iodine acceptor protein $(\mathrm{Tg})$. The active trapping I- from the blood by basolateral iodide transporter NIS and concentration in the thyroid gland is a first step of hormonogenesis. Then I- is translocated across apical membrane to the follicle lumen by apical anion transporter pendrin. Once the I- reaches the colloidal lumen it is quickly oxidized by TPO, the key enzyme of biosynthesis. Thyroperoxidase is localized as a dimer at the apical membrane colloid interface where the catalytic sites are exposed to the colloidal lumen, and where the main steps of hormonogenesis take place. Then oxidized iodide is further bound to tyrosyl residues in $\mathrm{Tg}-$ a precursor and storage form of thyroid hormones. The hormonogenic monoiodotyrosine (MIT) and diiodotyrosines (DIT) are subsequently coupled to form of T3 and T4. These key proteins engaged in the process of thyroid hormone synthesis are involved in pathological autoimmune response and genetic abnormalities in each of these proteins are responsible for some of thyroid disorders.

Published: 5 April 2013

Department of Biochemistry and Molecular Biology, The Centre of

Postgraduate Medical Education, Warsaw, Poland
doi:10.1186/1756-6614-6-S2-A13

Cite this article as: Czarnocka: The proteins of iodine metabolism in the pathophysiology of the thyroid gland. Thyroid Research 2013 6(Suppl 2): A13.
Submit your next manuscript to BioMed Central and take full advantage of:

- Convenient online submission

- Thorough peer review

- No space constraints or color figure charges

- Immediate publication on acceptance

- Inclusion in PubMed, CAS, Scopus and Google Scholar

- Research which is freely available for redistribution
C Biomed Central 